\title{
Characteristics and Promotion Research on Fashion Clothing E-marketing
}

\author{
Pingping Meng \\ TSL School of Business and Information Technology, Quanzhou Normal University, Quanzhou ,China \\ Email: 1981cindy@163.com
}

Received 2012

\begin{abstract}
The fashion clothing E-marketing is an important part of the fashion sales. E-marketing brings wider world for the clothing sales. This paper analyses the characteristics, the promotion method, and development suggestions of fashion clothing E-marketing. To sum up, the mature development of E-marketing promotes the development of the fashion clothing marketing.
\end{abstract}

Keywords: Fashion Clothing; E-marketing; Marketing Mode

\section{The Conception of and Relationship between Fashion Clothing and E-Marketing}

\section{The Conception and Characteristics of Fashion Clothing}

Generally, the clothes with novel styles and contemporaries are called fashion clothing. Fashion clothing must be composed of several fashion elements such as fashion style, fashion color, fashion pattern, etc. The fashion of clothing is a kind of social phenomenon and a kind of cultural, economic activity which transcends borders. It expresses people's favor of some styles, colors, fabrics, ways of dressing, etc. These elements are becoming a kind of expansive, epidemic phenomenon in whole society by people imitating of each other. The more notable the features of fashion clothing are, the more it shows a diverse era of pursuing personality and fashion.

The novelty, short-lived, popularity, and periodicity are the features of fashion clothing. Novelty is the most notable characteristic of fashion. Fashion is based on the psychology of consumers' pursuing of change and new expression. People hope to break through tradition and longer to approve of fresh. This, to clothing, mainly showed in the changing of style, fabric and color. So it's important to know people's psychology of caprice and requirement of seeking difference. Fashion clothing can't fashion for a long time. If a kind of clothing is accepted by most people, it denies the novelty of fashion clothing. Then people tend to seek for new kinds of clothing and the fashion clothing will be abandoned which means the recession of the fashion clothing. Only if the clothing is accepted by most target consumers can they be really fashion. Generally speaking, a dressing style which experienced the process of rise and decline will turn up in a new look after several years. As this is the periodicity of fashion clothing.

\section{The Conception and Effect of E-marketing}

E-marketing is a new way of marketing management which is based on internet, using digital information and interaction of network media to achieve marketing purpose. Simply put, E-marketing is a kind of marketing activity which uses internet as its main means to achieve certain marketing purpose.
E-marketing appeared after the present intermediary media such as newspaper, magazine, email, phone, television, etc. is a high technology media with powerful characteristics and adapts to the development of information age. It substantially takes advantage of internet to follow the tracks of the process of production marketing as pre-sale, sale and after-sale which includes market research, consumer analysis, product development, implementation of sales strategy, information collection and feedback etc. E-marketing is the product of the development of information technology. It is a business process which is based on modern marketing theory, using network technology and function in maximum to satisfy customer demand as to expand market and increase profit.

\section{The Relationship between E-marketing and Fashion Clothing}

Clothing E-marketing is a kind of clothing marketing activity which, clothing marketer, puts potential exchange into reality via modern communication technology and internet. E-marketing is closely related to fashion clothing. It is a marketing method which introduces the theories and practices of E-marketing to the field of clothing and applies network technology to the design of clothing.

Clothing E-marketing mainly conveys the image and fashion elements of the products. This is especially effective to the fashion clothing which has particular functions or forms. Popular clothing is special in E-marketing because of their features of novelty, transience and so on. E-marketing caters to fashion clothing, as a result, the fashion clothing have a better, faster development, dissemination and sales.

\section{The Situation and Features Analysis of Fashion Clothing E-Marketing \\ The Current Situation of the Domestic Clothing E-marketing}

The development of the fashion industry in our country is relatively, to other industries, in the medium level. According 
to statistics, nearly 55\% clothing enterprises in coastal developed areas have established their enterprise websites. However, the rest in these areas has not realized the importance of the construction of enterprise website. And in the Midwest, the number of enterprises with websites is less than $15 \%$ on average. Zhejiang, Guangdong, Shanghai, Jiangsu and Beijing are respectively in the top five, followed by Hunan in the absolute number of enterprise websites. The utilization rate of fashion industry is not high, but with the rise of Taobao, Paipai and Moonbasa, more and more individual operators begin to involve in the E-commerce marketing. Since 2002, there are tens of thousands of online shops opened including about $20 \%$ fashion clothing.

\section{Fashion Clothing E-marketing Features}

The Speed of Fashion Clothing E-marketing. The efficiency of fashion clothing is short-lived. It's about 3 months to a year. The changes of fashion elements and fashion cycles are becoming faster and faster. However, E-marketing has catered to the features of fashion clothing. The sales channels of E-marketing promote the speed and convenience of clothing trades. And this greatly shortens the cycle of new products facing the market. It's more and more convenient for the propaganda of products, buying patterns, payment patterns, feedback after sales etc.

The Space of Fashion Clothing E-marketing. The final goal of marketing is to possess market shares. E-marketing can exchange information beyond space restrictions with which marketing without space restrictions becomes possible and enterprises have more time and space on marketing. And to some extent, it avoids regional restrictions.

The Popularity of fashion Clothing E-marketing. The traditional way to disseminate information has great limitations in the face of the public. Generally, it's difficult to spread in extensiveness because of the effects of geographical location, cultural differences, social background, language environment etc. While E-marketing can find audiences, the specific form of audiences, all over the world by the advanced technologies. Thus, E-marketing can take enterprises to the field of electronic business and expand market at home and abroad.

The Rich-media of Fashion Clothing E-marketing. The internet can transmit a variety of media information such as texts, voices, images, etc. So the information of the trade can exist and exchange in many forms. And it can motivate the creativity and initiative of the marketer. It is convenient for propaganda since it has strong visual and auditory impact on consumers which can win deep impressions.

The Personality of Fashion Clothing E-marketing. Fashion clothing differs from man to man. Customers have their own preferences and they also have to consider of dressing and wearing effect. Fashion clothing market is more targeted and has more personality. E-marking avoids the disturb of marketer's strong sales which can be one-to-one, rational, consum-

1.Scientific research project of Quanzhou Normal University: "Fashion network communication and marketing research" (item: 2009KJ08). 2.Construction Funds of Master Degree Awarded Unit of Quanzhou Normal University.3.Fujian university key project construction service routines "The port logistics information platform construction, Haqixi prefecture", Project Number: A103. er-leading, unforced, progressive as well as low cost and humanized. It builds long-term good relationships between marketers and consumers while by communicating through information.

The Interaction of Fashion Clothing E-marketing. By showing the pictures and information of fashion clothing products on internet, it offers relevant references to realize the interactive communication between designers and consumers. In addition, it may also take the test of dressing effects and consumers satisfaction survey and so on. Network offers the best tool for the joint-design of popular clothing, the products launch as well as all kinds of technology services. This is convenient for designers to grasp market trend and satisfy customers maximally.

The Growth of Fashion Clothing E-marketing. With the maturity of the E-commerce environment in our country, the development of on-line shopping is entering into its golden time and the E-marketing sales of fashion clothing increases every year. Clothing enterprises and marketing teams are all updating marketing networks and building information systems. 'The petty bourgeoisies" have gradually got their scales to lead a new era of network consumption. In addition, the category differentiation in clothing field has not stopped especially the creativity of fashion clothing which is more in accord with the consumers' psychology of shopping. And the E-marketing of fashion clothing also has a huge development space.

The Advancement of Fashion Clothing E-marketing. The network is the most powerful marketing tool which includes various functions like channel, marketing, E-trade, interactive consumer service as well as marketing information analysis and supplication. It's this feature of the network that makes fashion clothing spread efficiently in an effective time.

The High Efficiency of Fashion Clothing E-marketing. The Internet has stored a lot of information to help consumers to search, inquire, analyze, compare and so on. It's easy to comply with the market and the demands of customers can be known effectively by updating products, classifying marketing or adjusting prices in time.

The Economy of Fashion Clothing E-marketing. E-marketing takes the exchange of information via internet instead of bartering in the past. The network can be used to launch information of the fashion products, transmit graphs, display products, put advertisements and communicate with consumers. E-marketing can reduce the cost of labor, printing, transport and delivery; can sale products without any real stores or rents; can save the cost of electricity and labor; and promote the efficiency of the deal by reducing the losses of circuitous exchange. Thus, the cost of E-marketing is one tenth in the comparison with relevant traditional business channels and practice in the same scale. And the strength of economy of operating cost in trade stands out.

\section{The Promotion Model of Fashion Clothing E-Marketing}

\section{The Marketing Website Model}

The Web site is a kind of marketing tool based on the Internet and almost all large and medium-sized enterprises and global institutions have set up their own Web sites to o attract as many page views as possible which meet the demand of users as well as make their own profits. To fashion clothing E-marketing, first, most of the brand clothing enterprises have 
their own official marketing web sites for launching the latest goods in time and realizing on-line shopping directly; Second, there are many professional marketing web sites which sale clothing mainly or at the range of clothing sales as Fashionmall, Amazon, Vancl, Moonbasa, etc. which also spread and sale the most fashion clothing. Third, some large professional clothing sites offer the information about the newest rag trade, such as the Global Textile, France Textile Information, Canada Leather, China fashion Brand, Chinese Export Trade, Chinese Clothing Brand etc. which provide chances of convenient trade to enterprises with enterprises, enterprises with consumers.

\section{The Online Store Model}

Except the function of sale products via network, online store is an efficient E-marketing tool as well. There are E-commerce models like BtoC (Business-to-Customer) and CtoC (Consumer to Consumer). And there are online store platforms like Taobao, Tmall, Paipai, leho, etc. which are specially constructed for individuals or enterprises. Online store offers advantages for enterprises to expand online sales channel. In addition, the online shop which set up on the famous E-commerce platform increases customer's trust. It's a kind of complement for the enterprise web which lacks of the function of E-commerce and it not only has good effects to promote the image of the enterprise but also combine the enterprise web with online store.

\section{The Search Engine Model}

The search engine is a system used for collecting various information resources on the Internet and then feed back the results to system according to users' search requests. The search engine marketing is a new kind of E-marketing model, which has been comprehensively and efficiently used for E-marketing and promotion via search engine. Search engine marketing pursues for the highest cost performance, which is to get the most page views from search engine and produce commercial value with the smallest input. Clothing enterprise improves the popularity of its enterprise clothing brand through the famous Google, Baidu and a series of search which makes it break into the fashion market quickly to take the initiative.

\section{The E-advertisement Model}

Clothing advertisement is a kind of persuasive information spreading activity on the related clothing products or the clothing brand images by clothing manufacturers or dealers or other advertisements subject to payment via the network information with features of payoffs, dependence and commerciality. Almost all the E-marketing activities are related to the brand images and the effect of E-advertisement is the most direct one among all relevant marketing methods about brand promotion.

\section{The Mailing List Model}

The mailing list is the earliest community form on the internet and an important tool in the internet which is used for the exchange and publishing of information among groups. The mailing list is a kind of E-mail marketing form based on the principle of users' permission which means users are free to join and exit. E-mail marketing sends the sales promotion to users directly while mailing list achieves marketing goals by providing users with valuable information.

\section{The BBS Communication Model}

People used BBS for all kinds of enterprise marketing activities at an early age. BBS communication is a kind of E-marketing activity which is used for enterprise to post its products and service information on the network communication platform---BBS by text, pictures, video, etc., so that the target customers can know more about the products and service of the enterprise, and finally, to achieve the goal of propagandizing the enterprise brand and deepening the market cognition. BBS activity has strong capability to gather folks and almost all of the marketing appeals can be realized effectively through the BBS spreading since the topics of BBS are very open.

There are well-known BBS at home and abroad such as Chuan Zhen Yin Xian clothing BBS, Chinese Clothing BBS, Chinese Apparel People BBS, Spider Fashion Conception and so on. The setting-up of different columns or layouts and uses of the high popularity of BBS can offer enterprises or individuals with efficient marketing spreading services. The professional BBS posts to offer the spreading of fashion clothing, the communication of designers, the appreciation of fashion collection, the discussion of competition, and the realization of marketing activity, etc. in the BBS space. It breaks through the traditional E-commerce model, uses the high popularity of community web sites and seeks for the new marketing model.

\section{The Online Chat Model}

The software such as QQ, MSN, TALK, CHAT, etc. with strong timeliness are the kinds of "one to one" private communication, which may be interconnected via locations of the Internets at random and at the same time. The biggest characteristic of them is their function of real time communication on line with "peer-to-peer", "face-to-face". The core of spreading is verbal and non-verbal. Verbal communication is through text mainly and non-verbal communication is by E-face, video, pictures and voice, etc. It's a kind of multimedia spread.

QQ group and chat room are "one-to-many" which are convenient for announcing news, spreading information and so on. The group or chat room can be established for the social groups which have common hobby such as fashion designers, fellowship of relevant enterprises, trade flows, fashion predictions, professional communication, etc. These innovative Internet services and shifting value-added services have profound effects on people's economic life and bring huge economic profits to the enterprises as well.

\section{The Viral Marketing Model}

The viral marketing is a common E-marketing method. It doesn't transmit virus in real but use the principle of public praises which spread rapidly like virus and use the way of fast copy to convey information to thousands of, millions of audiences. Thus, viral marketing becomes a high efficient way of information spread.

Viral marketing is almost free since it spreads among users spontaneously. This spread way of fast copy caters to the fea- 
tures of fashion clothing, so it has effects which can't be ignored in fashion clothing E-marketing.

\section{The Link Exchange Model}

The link exchange is a simple cooperation between two web sites which has certain complementary strengths. It puts the web site logo or key words of each others and sets the hyperlink on their own home page or inner sheet so that users can see their own web sites on the cooperating web site so as to achieve the goal of mutual promotion. The link exchange is helpful to attract customers who are surfing the net, to get page view, to increase the impression in users' browses, to add advantages in the rank of search engineer, to increase the trust of visitors via the recommendation of cooperating web site.

Link exchange lies in the cognition and approval in the industry. The portal nets of clothing enterprises increase visitor volume so as to speed up the spread of new fashion clothing products.

\section{The E-marketing Alliance Model}

The present E-marketing alliance is at developing stage in our country which has obtained good effects. The alliance includes advertisement owners, website owners and advertising alliance platform. The advertisement owners offer reasonable expenses to website owners according to the real effects of online advertisement. The fashion clothing enterprises and marketing departments can develop the sale by applying this kind of propaganda. This kind of marketing model can save the costs of marketing, boost popularity, expand the influence of apparel products and improve the quality of E-marketing.

\section{The Group purchase Model}

The group purchase is a very fashion shopping way in recent years which has experienced the stages of rise, climax, decline and steady. The group purchase is a kind of marketing model which gathers the manufacturers, retailers, customers to the group purchase websites or group purchase navigation websites letting them communicate without distance about the products design and creativities transform to realize the sale and service of the products.

Lashou web, Wowotuan, Meituan, etc. are the relatively famous webs which include some information about fashion clothing. Customers get favorable prices by shopping in group which are lower than buying separately. It's similar to form a small wholesaler by different people to get the wholesale price. The discount price attracts a large number of consumers to rush into the ranks of the group.

\section{The Microblog Marketing Model}

The microblog marketing uses the platform of microblog to do a series of marketing activities which include brand promotion, event planning, personal image packaging, product propaganda, etc. By registering a microblog in the name of individual, group or enterprise in the famous web site, they may update their own microblogs to communicate with the public or join the topic which is the interest of the public so as to achieve the goal of marketing.

Generally, the microblog of clothing enterprise has the features of rich pictures, video materials and huge impact of demonstrations. It can arouse the public attention through attention and forwarding; catch consumer's eyes through product experience and street shooting theme; publish some fashion information to increase attention or use the popular events for marketing. Similarly, clothing enterprises, individuals and groups can establish their own microblog, by updating their dynamics to accumulate consumption group, to make the communication between consumers and retailers more smoothly, offer more convenient channels of fast clothing commodity information to the enterprise.

\section{The Suggestions of Fashion Clothing E-Marketing}

\section{Grasping the Features of Fashion Clothing and Responding to the Market Demand Quickly}

The popularity of apparel commodity cycle is relatively short, through E-marketing with faster spreading speed in a wide range of region can urge the exchange to realize the value of enterprises and meet the demands of consumers. From this perspective, E-marketing has relatively unique advantages when compares with the traditional marketing.

The success of an enterprise does not just rely on innovation but more on quick response. As for the fashion industry which is famous for its timeliness, 'timeliness' and 'seasonality' consist of the notable features of clothing commodities and enterprises have to do information feedback efficiently, respond to market sensitively in the promotion of fashion clothing commodities so as to stand steadily in the more and more fierce market competition.

\section{Protecting Consumers Interests and Ensuring the Security of Network}

Network security includes personal login identity, individual account, and capital condition, email address, network activities trace and users' privacy information; the more important is consumers' account safety in the transaction. The relevant departments and enterprises should strengthen the development and application of electronic money payment system, improve its safety and reliability, and gradually make it mature and standardized. To promote the networked development of banks, to establish the full equipped electronic payment system in electronic trading payment and settlement means, it's necessary for the government to work out corresponding policies, laws and regulations for online shopping and protect online consumers.

It's an obligatory responsibility and obligation of clothing enterprises to ensure the security of network and protect the legal interests of consumers on the E-marketing. Only if clothing enterprises indeed, cogently protect the security of network can they reduce the risk of network and ensure the healthy and rapid development of E-marketing. 


\section{Strict Self-discipline, Enhancing Supervision, and Improving the Quality of Clothing Products}

The biggest hardship consumers meet in the online fashion clothing shopping is the quality of the product. The information and pictures on the web sites can't reflect the quality of the product objectively. Therefore, the enterprises and sellers should be in good faith, self-disciplined, and ensure the quality of fashion commodities, transact with each other with good faith and mutual benefits. In addition, the relevant departments should improve supervision and speed up the construction of legal system of E-marketing to protect the interests of online shopping consumers so as to make consumers feel relieved to buy pleasing commodities.

\section{Improving Sales Service System and Protecting Con- sumers' Rights and Interests}

The key point of E-marketing is to improve the quality of customer services on the net in order to achieve customers' satisfaction and loyalty, improve the efficiency of the marketing. The process of E-marketing service can be divided into pre-sale, sale and after-sale services. The pre-sale service mainly provides all sorts of relevant information services such as product propaganda and introduction and offer information through virtual E-market. Consumers compare prices and requirements and get products information in detail, promotion methods, logistics selection, etc. by exchanging information. The sale service includes trade negotiation, contracts execution or orders submission, and dealing with the relevant formalities before the trade, etc. The after-sale service includes performance of the transaction agreement, quality assurance, service and claim, etc.

It's one of the biggest worry of consumers online shopping because most of the retails are not perfect in the aspect of after-sale service in the fashion clothing E-marketing. It is important to deal with the return or replacement of goods, compensation and quality warranties, etc. perfectly when consumers have encountered any practical problems. The competition of after-sale service directly decides the success or failure of enterprises' marketing. Except good products, good after-sale service has become a kind of core competitiveness of enterprises and the enterprises shall take into account their quality of after-sale service seriously..

\section{Setting up Network Interactive System and Improving Network Business Environment}

The exchange of apparel commodity E-marketing results from good interaction. The interaction appears continually throughout the whole process of clothing E-marketing which is based on the demands of consumers. By using text, audio and video, the network interactive system displays the style, color, material, structure, contour, decorative detail, technology level and matching of clothing, offers online searching, communicates with consumers actively on the net in time, and take assessment and investigation of consumer satisfaction survey after service.

Lack of real environment and atmosphere of market, authen- ticity of the pictures and blurry of the effects are some problems in fashion clothing E-marketing. The clothing enterprises shall establish "virtual gallery" or entity shop to show the images of the products, use vivid images in the net to make consumers feel personally on the scene, choose models to demonstrate the commodities by multi-aspect which can stimulate consumers' desire to buy, offer facilitating conditions to improve the quality and quantity of consumers' shopping.

\section{Enhancing Technology of the E-marketing and Improving the E-commerce Trade Platform}

The current clothing E-marketing stays in a low level like poor technology, low network utilization rate, negative efficiency and so on. Enterprises and vendors should strengthen the construction of the web site, make novel layout, make it substantial in content, make it convenient to use, and reflect the spirit connotation of the commodities. And they shall also increase the investment in E-fitting technology, set up online fitting room or introduce fitting software to solve the problems of consumers' experience and feeling and reduce the risk of changing or refunding. Consumers can see their images of getting the clothes by the fitting software so as to determine purchase intention. Besides, enterprises and vendors should enhance background database technology, integrate interactive database marketing mechanism, develop and improve interact E-marketing system, provide complete automatic application mechanism, and use the features, interaction and real-time response of network.

The enterprises and vendors should select, design, develop and lead-in the E-commerce platform of E-marketing, combine the sales data of E-commerce platform and the enterprise's ERP(enterprise resource planning),SCM(supply chain management) via efficient exchange of information data to increase efficiency, save costs and integrate as well as apply enterprise's resources.

\section{Conclusions}

There are many benefits of E-marketing and there are various marketing models. The potential of our domestic clothing E-marketing is so great when compared with European and American countries where most of clothing retails are by E-marketing. While clothing E-marketing has been accepted by part of people as a new way of marketing, when it comes to the network popularization, the growth of its internet users and the consumption ability of the users, it still remains a huge market space to be expanded.

As a kind of special commodity, the E-marketing of the fashion clothing has both general and special features. The speed, convenience and 24-hours service of clothing E-market is beyond comparison with other real market. It breaks through traditional business obstacles. And it has big attractions and influences on consumers, enterprises and markets.

Definitely, the current fashion clothing E-marketing also has some problems on technology, hardware, consumer's psychology, delivery, etc. Thus, it's important to combine with the traditional fashion clothing marketing and E-marketing so as to display their respective merits and reach an ideal "win-win" 


\section{P. P. MENG}

model in the new economy era.

\section{REFERENCES}

NING Jun,Clothing E-marketing [M]. Beijing: China Textile Press,
2004. 1-3.

Liu Yun, E-marketing and planning[M], Beijing: Tsinghua University Press, 2010. 8

Wang Haining, Clothing E-marketing pattern and strategy are discussed. [J]. Jiangsu textile, 2006.02 